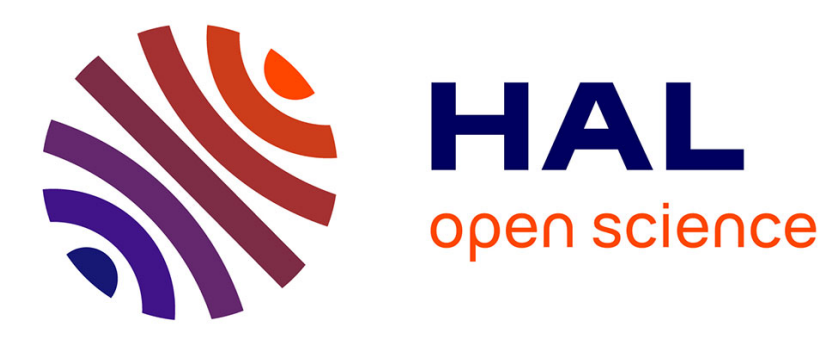

\title{
Regional Tax Competition: Evidence from French Regions
}

\author{
Yvon Rocaboy, Emmanuelle Reulier
}

\section{To cite this version:}

Yvon Rocaboy, Emmanuelle Reulier. Regional Tax Competition: Evidence from French Regions. Regional Studies, 2009, 43 (07), pp.915-922. 10.1080/00343400801932334 . hal-00516201

\section{HAL Id: hal-00516201 \\ https://hal.science/hal-00516201}

Submitted on 9 Sep 2010

HAL is a multi-disciplinary open access archive for the deposit and dissemination of scientific research documents, whether they are published or not. The documents may come from teaching and research institutions in France or abroad, or from public or private research centers.
L'archive ouverte pluridisciplinaire HAL, est destinée au dépôt et à la diffusion de documents scientifiques de niveau recherche, publiés ou non, émanant des établissements d'enseignement et de recherche français ou étrangers, des laboratoires publics ou privés. 


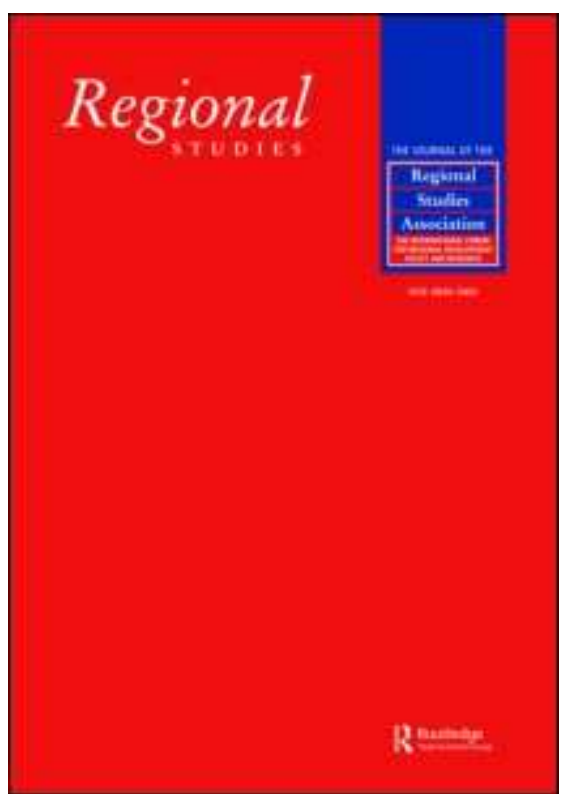

\section{Regional Tax Competition: Evidence from French Regions}

\begin{tabular}{|r|l|}
\hline Journal: & Regional Studies \\
\hline Manuscript ID: & CRES-2007-0162.R1 \\
\hline Manuscript Type: & Main Section \\
\hline JEL codes: & $\begin{array}{l}\text { H23 - Externalities; Redistributive Effects; Taxes and Subsidies < } \\
\text { H2 - Taxation, Subsidies, and Revenue < H - Public Economics, H41 } \\
\text { - Public Goods < H4 - Publicly Provided Goods < H - Public } \\
\text { Relations < H - Public Economics, H77 - Intergovernmental } \\
\text { Relations } \mid \text { Federalism < H7 - State and Local } \\
\text { Government|Intergovernmental Relations < H - Public Economics }\end{array}$ \\
\hline Keywords: & Yardstick Competion, Tax Competition, Local Taxes \\
\hline
\end{tabular}

\section{SCHOLARONE Manuscripts}




\title{
Regional tax competition: Evidence from French Regions
}

\author{
Emmanuelle REULIER \\ University of Rennes 1 and Centre National de la Recherche Scientifique (CREM-CNRS) \\ 7, Place Hoche, 35065 Rennes Cedex, France. \\ Email : emmanuelle.reulier@univ-rennes1.fr \\ Yvon ROCABOY \\ University of Rennes 1 and Centre National de la Recherche Scientifique (CREM-CNRS) \\ 7, Place Hoche, 35065 Rennes Cedex, France. \\ Email : yvon.rocaboy@univ-rennes1.fr
}

First received: June 2007

Accepted: November 2007

\begin{abstract}
Two mechanisms can lead to fiscal strategic interactions between local jurisdictions. The first one is due to the tax base mobility. Authorities use fiscal variables to attract new resources. The second one is related to information asymmetries between the politicians and the constituency. To reduce these asymmetries, voters can compare their fiscal situation to the one in neighbouring jurisdictions. These two channels lead to what we can refer to as "mobility-led" and "information-led" tax competition. This paper aims at discriminating among these two tax competition models in the case of the French regions. The econometric tests suggest that when taxes are paid by voters the politicians in office seem to be involved in an "information-led" tax competition, while in the case of taxes paid by firms, the mobility of the tax base seems to be the best way to explain strategic fiscal interactions.
\end{abstract}

Keywords: Yardstick competition, Tax competition, Local taxes

Compétition fiscale régionale: une étude

empirique sur les régions françaises. 
Résumé: Deux situations génèrent des interactions stratégiques fiscales entre collectivités territoriales. D'une part lorsque les bases imposables sont mobiles, les décideurs publics utilisent les variables fiscales pour attirer ces bases sur leur territoire. D'autre part, en cas d'information asymétrique en faveur des élus, les électeurs peuvent comparer leur situation fiscale à celles des collectivités voisines pour évaluer les performances de leurs représentants et les sanctionner aux élections en cas de résultats médiocres. Ce travail vise à identifier le vecteur des interactions fiscales entre régions françaises. Ces interactions seraient principalement dues à la mobilité des bases pour la taxe professionnelle, et au comportement de comparaison pour les taxes d'habitation et foncière bâtie.

Mots-clés : Compétition par comparaison, Compétition fiscale, Impôts locaux

JEL Classifications: D72, H73, H77

CRES-2007-0162.R1 (French abstract already provided)

Regionaler Steuerwettbewerb: Belege aus den französischen Regionen

Emmanuelle REULIER and Yvon ROCABOY

Abstract:

Es gibt zwei Mechanismen, die zu Wechselwirkungen zwischen den

Fiskalstrategien verschiedener lokaler Verwaltungsbezirke führen können. Der erste Mechanismus ist in der Mobilität des Steuerwohnsitzes begründet. Durch

Verwendung fiskaler Variablen bemühen sich die Behörden um die Anwerbung neuer Ressourcen. Der zweite Mechanismus steht im Zusammenhang mit den Informationsasymmetrien zwischen Politikern und Wählerschaft. Um diese Asymmetrien zu verringern, können die Wähler ihre fiskale Situation mit der von Wählern in angrenzenden Verwaltungsbezirken vergleichen. Diese beiden Kanäle führen zu einem steuerlichen Wettbewerb, der sich als 'mobilitätsgeführt' und 'informationsgeführt' bezeichnen lässt. In diesem Beitrag wird versucht, anhand des Beispiels der französischen Regionen zwischen diesen beiden steuerlichen Wettbewerbsmodellen zu unterscheiden. Die ökonometrischen Tests lassen darauf schließen, dass die amtierenden Politiker bei Steuern, die von Wählern gezahlt werden, sich an einem 'informationsgeführten' steuerlichen Wettbewerb zu beteiligen scheinen, während im Fall von Firmensteuern die Mobilität des 
Steuerwohnsitzes die beste Erklärung für strategische fiskale Wechselwirkungen zu sein scheint.

Keywords:

Yardstick-Wettbewerb

Steuerlicher Wettbewerb

Lokalsteuern

JEL Classifications: D72, H73, H77

\title{
CRES-2007-0162.R1 (French abstract already provided)
}

Competición impositiva regional: ejemplo de las regiones francesas

\section{Emmanuelle REULIER and Yvon ROCABOY}

\begin{abstract}
:
Existen dos mecanismos que pueden llevan a interacciones estratégicas fiscales entre las jurisdicciones locales. El primero se debe a la movilidad de base impositiva. Las autoridades usan las variables fiscales para atraer nuevos recursos. El segundo está relacionado con las asimetrías de información entre los políticos y los votantes. Para reducir estas asimetrías, los votantes pueden comparar su situación fiscal con las de jurisdicciones vecinas. Estos dos canales conducen a lo que denominamos competición fiscal 'conducida por la movilidad' y 'conducida por la información'. En este artículo comparamos estos dos modelos de competición fiscal en el caso de las regiones francesas. Las pruebas econométricas indican que cuando los votantes pagan los impuestos, los políticos en funciones parecen participar en una competición impositiva 'conducida por la información', mientras que en el caso de los impuestos pagados por empresas, la movilidad fiscal parece ser la mejor manera de explicar las interacciones fiscales estratégicas.
\end{abstract}

Keywords:

Competición Yardstick

Competición impositiva

Impuestos locales

JEL Classifications: D72, H73, H77

1. Introduction 
Since the late nineties many studies have dealt with the strategic interactions between tax policy among countries or local governments. There are two main channels through which interactions take place. The first one is based on the mobility of tax bases. Under this assumption, stressed among others by Wildasin (1988), an action chosen by a jurisdiction affects the budget constraint of another jurisdiction, by means of a policy-driven resource flow among localities, leading to strategic interactions in local public decisions. The second channel due to Salmon (1987) and Besley and Case (1995) consists of information. Some of the politicians are supposed to be opportunist and hold private information not available to voters. The latter have the possibility to compare their situation to the one prevailing in the nearby jurisdictions and to gauge the relative performance of their representatives. Anticipating this yardstick behaviour, the politicians take into account not only the program of their competitors in their own jurisdiction but also decisions made in the neighbouring communities. These two channels lead to what we can refer to as "mobility-led" tax competition (commonly known as tax competition) and "information-led" tax competition (also known as yardstick competition).

In both cases, we can establish a theoretical correlation between the tax rates of neighbouring jurisdictions. Indeed, in order not to suffer a tax base shrinking, or not to be considered as bad politicians, decision-makers rationally adopt mimicking behaviours. Empirical studies have found the existence of such correlations at the decentralized level of government in Europe. It is, for example, the case in Germany (Buettner, 2001), Finland (Kangasharju et al, 2006), Spain (Bosh and Solé-Ollé, 2007), Switzerland (Feld and Kirchgässner, 2001), France (Feld, Josselin and Rocaboy, 2003), and the Netherlands (Allers and Elhorst, 2005). 
In this paper we examine this question but in a rather different way. We use the features of the French local tax system to discriminate among the two competing theories. There are two kinds of local taxes in France: taxes paid by firms and taxes paid by voters. The mobility of firms is potentially higher than that of voters. A priori, if interaction exists for both kinds of taxes, mobility would be the best way to explain it for taxes paid by firms, whereas information would be responsible for interaction concerning taxes paid by voters. Moreover in that latter case, we assume that inferring the right tax level from observing the fiscal situations in the neighbouring jurisdictions may be a complicated task for voters, particularly when tax rates are very different from one jurisdiction to another. As a result, the opportunist politicians may take advantage of the complexity of the comparison to increase tax rates in their own jurisdictions. In that case, under the "Yardstick competition" hypothesis, there should be a positive correlation between the variance of the nearby tax rates and the tax rates of a jurisdiction, ceteris paribus. We investigate this question in the case of local taxes at the regional level in France. We find that the taxes paid by voters in one French region - a housing tax (Taxe d'habitation) and a property tax (Taxe foncière) - 
depend positively on the average tax rates of geographically neighbouring regions and on the standard-deviation of these tax rates. The larger the standard deviation of neighbouring tax rates, the more complicated the comparison is, and the easier it is for politicians to increase tax rates. However, this "complicated comparison effect" is not significant when the business tax (Taxe professionnelle) is considered. This strengthens the idea that comparison would be an important element of the local tax system for voters, whereas tax base mobility would be the channel of the interactions among jurisdictions in the case of taxes addressing firms. Section 2 briefly summarizes these arguments, section 3 presents the econometric tests and the last section concludes the paper.

\section{The tax competition theories}

The models of local strategic interactions based on capital mobility have the same theoretical foundations (Wildasin, 1988). Local public decision-makers are supposed to maximise a welfare function positively related to the local public good level. Voters are assumed to be immobile and to consume both a private good and a local public good. The latter is financed by a tax on capital. Since capital is assumed to be perfectly mobile across local jurisdictions, when a given government raises its tax rate, net return on capital located there falls and then capital chooses to relocate. Marginal productivity of capital within the jurisdiction of departure increases, while marginal productivity of the jurisdiction of arrival decreases. Capital flows carry on until the net return on capital becomes identical everywhere. Formally, $f_{l}^{\prime}\left(k_{l}\right)-t_{l}=\rho, l=1, L$ and $\sum_{l} k_{l}=\bar{k}$ where $f_{l}^{\prime}$ is capital marginal productivity in jurisdiction $l\left(f_{l}{ }^{\prime}>0>f_{l}{ }^{\prime \prime}\right), k_{l}$ is the stock of capital located in $l, t_{l}$ is the tax rate on capital in $l, \bar{k}$ is the total amount of capital in the economy and $L$ the number of 
jurisdictions. From this system of equations, we can easily compute the change in capital in jurisdiction $i$ that results from altering marginally the tax rate in $i$, ceteris paribus. This change is given by:

$$
\partial k_{i} / \partial t_{i}=\frac{1}{\sum_{l=1}^{L} f_{l}^{\prime \prime}}<0
$$

A jurisdiction may be induced to lower tax rate in order to attract capital and then to increase local public expenditures. For instance, if we assume that the goal of the decision maker in $i$ is to maximise the tax revenue coming from the taxation on capital, the tax rate in $i$ results from the following maximisation problem:

$$
\underset{\left\{t_{i}\right\}}{\operatorname{Maximise}} R_{i}=t_{i} k_{i}\left(t_{1}, \ldots, t_{i}, \ldots, t_{L}\right)
$$

The first order condition which is also the Cournot-Nash reaction function of jurisdiction $i$ is given by:

$$
k_{i}\left(t_{1}, \ldots, t_{i}, \ldots, t_{L}\right) \sum_{l=1}^{L} f_{l}^{\prime \prime}\left(k_{l}\left(t_{1}, \ldots, t_{i}, \ldots, t_{L}\right)\right)+t_{i}=0
$$

Consequently, under the assumption of perfect mobility of capital, a change in tax rate in one jurisdiction systematically alters the allocation of capital in the region and results in a change in tax rates in the other jurisdictions. This is the "mobility-led" tax competition hypothesis.

Salmon (1987) and more recently Besley and Case (1995) have used alternative or complementary explanations of public decision-making processes in a setting of fiscal federalism. These authors dropped the concept of mobility as explanation for fiscal interactions. In their framework fiscal interactions are mainly based on information asymmetries between voters and their representatives. In a world of imperfect and 
asymmetric information, voters have restricted possibilities to evaluate the performance of the representatives. Selfish representatives aim at gathering political rents and hence have incentives to withhold information about their opportunistic behaviour from voters. However, voters can draw inferences on politicians' behaviour, by comparing it to the performance of governments and parliaments in neighbouring jurisdictions. Other things being equal, these neighbours serve as yardsticks for the voters' evaluation. A bad performance in their own jurisdiction compared to other jurisdictions will penalize representatives, and their chance of being re-elected drops. Under this theory, public choice is not only driven by information gathering from neighbouring jurisdictions, but also by fiscal strategic interactions. Because representatives anticipate the yardstick mechanism, they are able to stay in power by adapting to the policies of their neighbours.

A constraint on this theory is that the voters' capacity to compare different fiscal situations may be limited. When the fiscal or institutional situations in the neighbouring jurisdictions are very complex, it may be difficult for the voters to decipher the right tax level from comparison. For example, Alt et alii (1998) show in the case of the US States, that when the executive and the legislative power are controlled by different parties, increasing tax rate does not result in electoral sanction. This may be because the voters find it difficult to identify the politicians responsible for this tax increase.

More generally, complexity of local tax systems may be an obstacle for yardstick competition to contain opportunistic behaviour. The following simple model is an illustration of this hypothesis (see Reulier and Rocaboy (2007) for a more detailed presentation of the yardstick competition hypothesis). Suppose the (re)-election probability 


$$
1+\Delta \frac{\partial p_{i}\left(t_{i}, t_{i}^{v}, \sigma_{i}^{v}\right)}{\partial t_{i}}=0
$$

and the second order condition:

$$
\frac{\partial^{2} p_{i}\left(t_{i}, t_{i}^{v}, \sigma_{i}^{v}\right)}{\partial t_{i}^{2}}<0
$$

From the first order condition 5 and using the implicit function theorem we can deduce the effect of an increase in $\sigma_{i}^{v}$ on $t_{i}$ :

$$
\frac{d t_{i}}{d \sigma_{i}^{v}}=-\frac{\partial^{2} p_{i} / \partial t_{i}^{2}}{\partial^{2} p_{i} / \partial t_{i} \partial \sigma_{i}^{v}}
$$

Therefore, if the marginal probability of being (re)-elected $\left(\partial p_{i} / \partial t_{i}\right)$ depends positively on $\sigma_{i}^{v}$ (i.e. $\partial^{2} p_{i} / \partial t_{i} \partial \sigma_{i}^{v}>0$ ) or in other words if the marginal probability of being defeated depends negatively on $\sigma_{i}^{v}$, an increase in $\sigma_{i}^{v}$ results in an augmentation of the tax rate in $i$. 
Both theories conclude to the existence of fiscal strategic interactions at the local level of government, as suggested by equations 3 and 5. The decisive difference between these two models lies in the fact that firms respond immediately to a modification in the local tax rates by moving (see equation 1). The reason is that companies pay local taxes for obtaining the right to locate somewhere. If the tax rate increases relatively more in one jurisdiction, firms decide to flee that jurisdiction and relocate in one of the neighbouring jurisdictions where the "location price" has remained unchanged.

The situation is different in the case of voters. For the voters, increasing the tax rate means benefiting from a larger quantity of local public goods or from local public goods of better quality. The problem is that relevant information may not be available to voters. The opportunist politicians can then take advantage of this situation to collect more tax revenue than the amount required to finance the voters' optimal level of local public goods. And justifying an increase in tax rate is easier if the information held by voters is not very clear. This is the "complicated comparison effect". This effect does not exist in the case of the "mobility-led" tax competition hypothesis. In what follows we test for the existence of such an effect in the case of the French local public sector.

\section{The econometric analysis}

We begin with a short description of the French local public sector. By decreasing size, the three levels of local government in France are the "régions", then the "départements", the lower level being that of the "communes" (municipalities) and their co-operation structures. 
The regional level is the object of this study. The French regions are mainly responsible for higher education and economic development. Around 50\% of the local public expenditures at the regional level are financed through taxation; the other $50 \%$ comes from grants received from the central government. There are four main local taxes in France: a tax on housing independent of the property status (taxe d'habitation), two property taxes on properties with and without buildings (respectively taxe foncière sur les propriétés bâties, and taxe foncière sur les propriétés non-bâties), and a local business tax (taxe professionelle).

Business tax accounts for $50 \%$ of total tax revenue, while the housing tax and the property tax with buildings represent respectively $23 \%$ and $25 \%$ of total revenue. The remaining $2 \%$ comes from the property tax without buildings. The rental value of housing is the tax base of the housing tax and the property taxes, while the business tax is mainly based on the capital of firms located in the jurisdiction. The housing tax and the property taxes are paid by voters, while the business tax is paid by firms.

This specificity enables us to test for the existence of a "complicated comparison effect" in the case of taxes paid by voters, namely the housing tax and the property tax, while in the case of the business tax such an effect should not exist. The fact that getting information from comparison may be a complicated task for voters is illustrated in Figure 1. This figure displays the housing tax rate for the 22 French regions for year 1989. It is probably more complicated to draw inferences on politician behaviour by comparing it with neighbours' politician behaviour for voters living in region Limousin than it is for voters living in region Bretagne. The tax rate in the regions bordering with region Bretagne i.e. Basse Normandie and Pays de Loire are pretty close, respectively 1.55 and 1.34 . The situation is radically 
different in region Limousin. Tax rate in neighbouring jurisdictions ranges from 0.9 to 1.69 . It is certainly more politically risky for politicians in region Bretagne to unilaterally increase tax rate than it is for those in region Limousin.

Figure 1 about here

The empirical tests are performed over the period 1986-1999 for the 22 French regions. The econometric model arises from the standard tax-setting equation where strategic interactions are considered. The only difference is in the explained variable set in which we add the standard deviation in neighbours' tax rates. This variable is used to measure the difficulty of comparison. The higher the standard deviation, the more complicated the comparison is ${ }^{1}$. The tax-setting model can be written in matrix form:

$$
t=c U+\alpha t^{v}+\gamma \sigma^{v}+\beta X+V
$$

where:

- $\quad t$ is the vector of the regions' tax rates.

- $\quad t^{v}$ is the vector of the average of regions' geographic neighbours' tax rates lagged by one period ${ }^{2}$. In this paper we suppose that region $i$ and region $j$ interact if region $i$ is bordering with region $j$. Moreover, we assume that the bordering regions have an identical influence whatever the region. Under these assumptions, the variable $t^{v}$ for each region $i$ corresponds to the average of the tax rates of the bordering regions: $t_{i}^{v}=\left(\sum_{b_{i} \in B_{i}} t_{b_{i}} / \operatorname{Card}\left(B_{i}\right)\right)$ where $B_{i}$ is the set of regions $b_{i}$ bordering with $i$ and $t_{b_{i}}$ is the tax rate in region $b_{i}{ }^{3}$. 
- $\quad U$ is the unity vector.

- $\quad X$ is the matrix of $k$ observable regions' economic and demographic characteristics lagged by one period: Population, Population density, Average household income, Unemployment rate, and grants per capita.

- $\quad V$ is the vector of the error terms which are assumed to be normally distributed with zero mean and constant variance.

Finally, we have to take into account three features of this model. First, French local governments are not completely free in the matter of tax rate setting. A few limiting rules exist which imply some links between the rates of the four taxes. In order not to bias our estimates because of the existence of such links, we use a simultaneous-equations model with four equations similar to equation 8 corresponding to the four French local taxes. Second, there is an endogeneity problem. Hausman tests reveal that the neighbouring tax rates are endogenous, so that we cannot estimate this system by OLS. The structure in the panel-data allows us to use the instrumental variable method and choose as instruments the average demographic and economic characteristics of the neighbouring regions as proposed by Kelejian and Robinson (1993) and Kelejian and Prucha (1998). Third, we use the 
Generalized Method of Moments (GMM) estimator ${ }^{5}$ to correct for autocorrelation of errors and heteroscedasticity implied by the panel-data structure of the model. Besides, to control for all time-specific spatial-invariant variables whose omission could bias the estimates in a typical time-series study, we have introduced time period fixed effects. The estimation results are given in table 1.

\section{Table 1 about here}

The adjusted coefficient $R^{2}$ ranges from 49 to $69 \%$ and is greater than $60 \%$ for the three main regional taxes: the housing tax, the tax on properties with buildings and the business tax. The coefficient $\alpha$ of strategic interactions is individually and globally significant at the $1 \%$ significance level for the four taxes. The higher the average of the tax rates of the neighbouring regions, the higher the tax rate in the region under consideration. The size of the coefficients reflects that tax mimicking occurs to a large extent for the four regional tax rates. For instance, for the business tax, a 1 point increase in the neighbouring regions average tax rate leads to a significant rise of 0.798 point in the tax rate of the region under consideration. As regards the housing tax, a Wald test indicates that the interaction coefficient is not significantly different from the unity.

Regarding the impact of the other variables, population generally has a significant negative effect on tax rates. This means that the price elasticity of demand for local public goods is low. An increase in the regional population yields a decrease in the tax price for taxpayers, thus slightly increasing the local public good provision and then reducing the tax rates. The income per head variable has a significant negative impact on tax rates for three of the four 
regional taxes. In the same vein, the variable grants per capita is statistically significant at the $1 \%$ level for the property tax with buildings and the business tax and have a negative sign in the four tax setting equations. The unemployment rate and population density do not have any significant impact in any of the four equations. Besides, as suggested in table 1 the hypothesis that there are no time fixed effects is rejected at $1 \%$ level.

Finally as suggested by the theory the coefficient $\gamma$ of the standard deviation of the neighbouring regions tax rates is individually statistically significant only for the housing tax and the property tax with buildings and they both have the expected effect. Indeed, for these two taxes paid by voters, the higher the standard deviation, the higher the tax rates, ceteris paribus. This may be because opportunist politicians can take advantage of the complexity of the comparison to increase the tax rates.

However, the Jarque-Bera statistical tests show that the error terms are not normally distributed. A study of the error terms enables us to identify the regions with a different behaviour. These regions are Corsica, Picardy, Limousin, Centre and Basse-Normandy which are mainly rural regions. After having addressed this problem, the results of the new estimations are displayed in table 2 . The goodness of fit is widely improved. It is 64 to $78 \%$ of the variation which is now explained by the model. The coefficient of fiscal interactions remains statistically significant for the four regional taxes, although smaller than in the previous estimations. As for the housing tax, a 1 point increase in the average of the neighbouring tax rates results in a 0.954 points increase in the rate of the region under consideration. The "complicated comparison effect" is still statistically significant for the 
housing tax and the property tax but not for the business tax. The results remain globally unchanged for the other variables.

Table 2 about here

\section{Conclusion}

The empirical findings suggest that the French regions adopt strategic behaviour when setting tax rates. It seems, however, that the motivations of this behaviour differ depending on whether the tax is paid by voters or by firms. On the one hand, when taxes are paid by voters (tax on properties with buildings and housing tax) the politicians in office seem to be involved in an "information-led" tax competition. They adopt tax mimicking behaviour so as to maximize their chances of being re-elected. But the more complicated the comparison is for voters, the easier it is for opportunist politicians to increase tax rates. On the other hand, for the business tax, the mobility of the tax base seems to be the best way to explain fiscal interactions. The "complicated comparison effect" is not significant in that case.

In addition, yardstick competition is often considered as a way to contain opportunistic politician behaviour. The existence of the "complicated comparison effect" calls into question this property. When the information available to the voters is fuzzy, it is easier for the politicians to justify a tax rate increase, making more difficult the identification of bad political decisions.

Acknowledgements 
We would like to thank seminar participants at the Government Institute for Economic Research (VATT, Helsinki), the School of Policy of the University of Newcastle, Australia, and the Department of Economics of Macquarie University, Sydney, Australia, for helpful comments and suggestions. We are also grateful for comments received from a referee of this journal. The paper is part of the ACI Programme "Local public goods, Politics, and Economics" headed by Hubert Kempf and financially supported by the Centre National de la Recherche Scientifique (CNRS).

\section{NOTES}

1. We tried the coefficient of variation instead of standard deviation. It gave significant results but standard deviation performed better.

2. We have used a row-standardized contiguity matrix, i.e., the spatial weight matrix is normalized so the rows sum to unity. This standardization produces a spatially dependent lagged variable that represents a vector of average values from neighbouring dependent observations.

3. In the case of $i=$ Bretagne: $B_{i}=\{$ Basse-Normandie, Pays de Loire $\}$, and then $t_{i}^{v}=(1.55+1.34) / 2=1.445$ (see figure 1 ). We tried several other weighting matrices based on alternative criteria, such as similarity among jurisdictions in population structure, similarity in per capita income, and the inverse of the distance between the capitals of regions. None of them, though, led to significant improvements upon the basic unweighted border sharing specification. 
4. In the case of $i=$ Bretagne, $\sigma_{i}^{v}=0.105$.

5. Estimations are performed with Eviews 4.1, Generalized Method of Moments under the options: "Time series (HAC), one step weighting matrix, iterate coefficient, Prewhitening, Kernel Options Bartlett, Bandwidth selection fixed (5)".

\title{
REFERENCES
}

Allers M. and Elhorst J. (2005) Tax Mimicking and Yardstick Competition Among Local Governments in the Netherlands, International Tax and Public Finance 12, 493-513.

\begin{abstract}
Alt J.E., Lowry R.C. and Ferree K.E. (1998) Fiscal policy and electoral accountability in American States, American Political Science Review 88, 811-828.
\end{abstract}

Besley T. and Case A. (1995) Incumbent behavior: Vote seeking, tax setting and yardstick competition, American Economic Review 85, 25-45.

Bosh N. and Solé-Ollé A. (2007) Yardstick Competition and the Fiscal Cost of Raising Taxes: An empirical Analysis of Spanish Municipalities, International Tax and Public Finance 14, 71-92.

Brett C. and Pinske J. (2000) The determinants of municipal tax rates in British Columbia, Canadian Journal of Economics 33, 695-714. 
Buettner T. (2001) Local capital income taxation and competition for capital: The choice of the tax rate, Regional Science and Urban Economics 31, 215-245.

Feld L.P and Kirchgässner G. (2001) Income tax competition at the state and local level in Switzerland, Regional Science and Urban Economics 31, 181-213.

Feld L.P., Josselin J.M. and Rocaboy Y. (2003) Tax mimicking among regional jurisdictions, in Marciano A. and Josselin J.M. (eds), From economic to legal competition. New perspectives on law and institutions in Europe, London : Edward Elgar, 105-119.

\author{
Kangasharju A., Moisio A., Reulier E., and Rocaboy Y. (2006) Tax competition among \\ municipalities in Finland, Urban Public Economics Review 5, 13-24.
}

Kelejian, H.H. and Prucha I.R. (1998) A generalized spatial two-stage least squares procedure for estimating a spatial autoregressive model with autoregressive disturbances, Journal of Real Estate Finance and Economics 17, 99-121.

Kelejian, H.H. and Robinson D.H. (1993) A suggested estimation for spatial interdependent models with autocorrelated errors, and an application to a county expenditure model, Papers in Regional Science 72, 297-312. 
Reulier E. and Rocaboy Y. (2007) Finite-Lived politicians and Yardstick Competition, Journal of Public Finance and Public Choice, n. 2006-1, 23-40.

Salmon P. (1987) Decentralization as an incentive scheme, Oxford Review of Economic Policy 3, 24-43.

Wildasin D.E. (1988), Nash equilibria in models of fiscal competition, Journal of Public Economics 35, 229-240.

Figure 1: The average Housing tax (Taxe d'habitation) for the 22 French regions in 1989. 


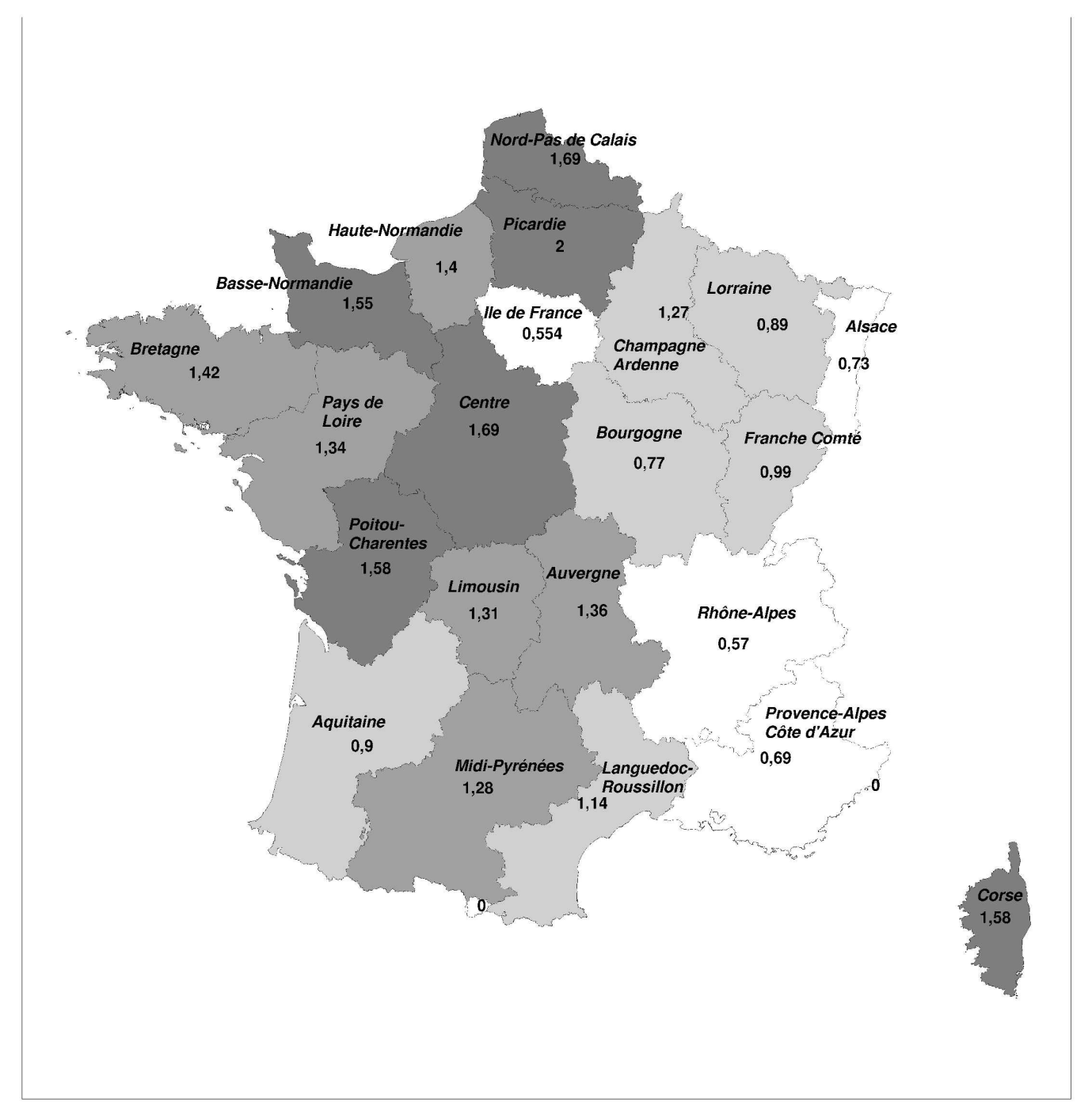

Table 1: Model of fiscal strategic interactions among the 22 French Regions, GMM, 1986 to 1999 


\begin{tabular}{|c|c|c|c|c|c|}
\hline & $\begin{array}{l}\text { Tax rate } \\
\text { of the housing } \\
\quad \operatorname{tax}\end{array}$ & $\begin{array}{l}\text { Tax rate of the } \\
\text { Property tax } \\
\text { (with buildings) }\end{array}$ & $\begin{array}{l}\text { Tax rate of the } \\
\text { local business tax }\end{array}$ & $\begin{array}{c}\text { Tax rate of the } \\
\text { Property tax } \\
\text { (without buildings) }\end{array}$ & $\chi^{2}$ \\
\hline Constant & \multicolumn{4}{|c|}{$\begin{array}{r}2.161^{*} \\
(2.37) \\
\end{array}$} & $5.63^{*}$ \\
\hline $\begin{array}{c}\text { Tax rate of neighbouring } \\
\text { regions: } t^{v}\end{array}$ & $\begin{array}{l}1.171 * * \\
(5.50)\end{array}$ & $\begin{array}{c}0.791 * * \\
(3.12)\end{array}$ & $\begin{array}{c}0.798 * * \\
(3.62)\end{array}$ & $\begin{array}{c}0.885^{* *} \\
(3.39)\end{array}$ & $53.41 * *$ \\
\hline $\begin{array}{l}\text { Standard deviation of the } \\
\text { tax rate of neighbouring } \\
\text { regions: } \sigma^{v}\end{array}$ & $\begin{array}{l}0.899 * * \\
(3.45)\end{array}$ & $\begin{array}{c}0.971 * * \\
(3.26)\end{array}$ & $\begin{array}{l}0.204 \\
(0.82)\end{array}$ & $\begin{array}{l}-0.185 \\
(-0.54)\end{array}$ & $18.69 * *$ \\
\hline Population & $\begin{array}{r}-0.007 * \\
(-2.56)\end{array}$ & $\begin{array}{c}-0.019 * * \\
(-3.12)\end{array}$ & $\begin{array}{l}-0.005 \\
(-1.13)\end{array}$ & $\begin{array}{c}-0.074 * * \\
(-4.05)\end{array}$ & $27.01 * *$ \\
\hline Population Density & $\begin{array}{l}0.001 \\
(1.10)\end{array}$ & $\begin{array}{l}0.001 \\
(0.81)\end{array}$ & $\begin{array}{l}0.000 \\
(0.41)\end{array}$ & $\begin{array}{l}0.003 \\
(1.32)\end{array}$ & 3.37 \\
\hline Income per capita & $\begin{array}{c}-0.003^{*} \\
(-2.34)\end{array}$ & $\begin{array}{c}-0.003^{*} \\
(-1.99)\end{array}$ & $\begin{array}{r}-0.002 * \\
(-2.04)\end{array}$ & $\begin{array}{c}-0.000 \\
(-0.08)\end{array}$ & 7.28 \\
\hline Unemployment rate & $\begin{array}{l}-0.023 \\
(-1.33)\end{array}$ & $\begin{array}{l}0.019 \\
(0.50)\end{array}$ & $\begin{array}{l}0.001 \\
(0.05)\end{array}$ & $\begin{array}{l}0.060 \\
(0.71)\end{array}$ & 5.74 \\
\hline Grants per capita & $\begin{array}{l}-0.002 \\
(-0.54)\end{array}$ & $\begin{array}{l}-0.42 * * \\
(-7.00)\end{array}$ & $\begin{array}{c}-0.048 * * \\
(-7.30)\end{array}$ & $\begin{array}{l}-0.021 \\
(-1.51)\end{array}$ & $87.79 * *$ \\
\hline $\begin{array}{l}\text { Time period fixed effects: } \\
\qquad \chi^{2}\end{array}$ & $82.07 * *$ & $60.03 * *$ & $77.40 * *$ & $30.35 * *$ & \\
\hline$\overline{R^{2}}$ & 0.69 & 0.62 & 0.61 & 0.49 & \\
\hline S.E.R. & 0.30 & 0.58 & 0.40 & 1.58 & \\
\hline Jarque-Bera & $33.86 * *$ & $8.60^{*}$ & $622.84 * *$ & $12.10^{* *}$ & \\
\hline
\end{tabular}

Notes : Estimations performed with Eviews 4.1, Generalized Moment Method under the options : "Time series (HAC), one step weighting matrix, iterate coefficient, Pre-whitening, Kernel Options Bartlett, Bandwidth selection fixed (5)". The numbers in parentheses are the values of the estimated t-statistics. '**', '*', '(*)' show that the estimated parameter is significantly different from zero at the 1,5 , or 10 percent level respectively. SER is the standard error of the regression. and Jarque-Bera the statistic of the Jarque-Bera statistical test.

Tableau 2 Model of fiscal strategic interactions among the 22 French Regions, GMM, Robust estimations, 1986 to 1999 


\begin{tabular}{|c|c|c|c|c|c|}
\hline & $\begin{array}{l}\text { Tax rate } \\
\text { of the } \\
\text { housing tax }\end{array}$ & $\begin{array}{l}\text { Tax rate of the } \\
\text { Property tax } \\
\text { (with buildings) }\end{array}$ & $\begin{array}{l}\text { Tax rate of the } \\
\text { local business tax }\end{array}$ & $\begin{array}{c}\text { Tax rate of the } \\
\text { Property tax } \\
\text { (without buildings) }\end{array}$ & $\chi^{2}$ \\
\hline Constant & \multicolumn{4}{|c|}{$\begin{array}{r}2.666^{* *} \\
(2.85) \\
\end{array}$} & $8.16^{* *}$ \\
\hline $\begin{array}{c}\text { Tax rate of neighbouring } \\
\text { regions: } t^{\nu}\end{array}$ & $\begin{array}{l}0.954^{* *} \\
(5.01)\end{array}$ & $\begin{array}{c}0.638^{* *} \\
(2.93)\end{array}$ & $\begin{array}{c}0.775^{* *} \\
(3.95)\end{array}$ & $\begin{array}{c}0.758 * * \\
(2.83)\end{array}$ & $37.30 * *$ \\
\hline $\begin{array}{c}\text { Standard deviation of the } \\
\text { tax rate of neighbouring } \\
\text { regions: } \sigma^{v}\end{array}$ & $\begin{array}{l}0.650^{* *} \\
(3.04)\end{array}$ & $\begin{array}{c}0.916^{* *} \\
(3.26)\end{array}$ & $\begin{array}{l}0.125 \\
(0.66)\end{array}$ & $\begin{array}{l}-0.010 \\
(-0.03)\end{array}$ & $14.23 * *$ \\
\hline Population & $\begin{array}{c}-0.007 * * \\
(-2.86)\end{array}$ & $\begin{array}{l}-0.001 * \\
(-2.33)\end{array}$ & $\begin{array}{l}-0.004 \\
(-1.16)\end{array}$ & $\begin{array}{c}-0.006 * * \\
(-3.01)\end{array}$ & $17.23 * *$ \\
\hline Population Density & $\begin{array}{c}0.001(*) \\
(1.68)\end{array}$ & $\begin{array}{l}0.001 \\
(0.88)\end{array}$ & $\begin{array}{l}0.000 \\
(0.94)\end{array}$ & $\begin{array}{l}0.003 \\
(1.08)\end{array}$ & 4.50 \\
\hline Income per capita & $\begin{array}{c}-0.003 * * \\
(-2.80)\end{array}$ & $\begin{array}{c}-0.004 * * \\
(-2.73)\end{array}$ & $\begin{array}{c}-0.003 * * \\
(-2.80)\end{array}$ & $\begin{array}{l}-0.002 \\
(-1.10)\end{array}$ & $8.00(*)$ \\
\hline Unemployment rate & $\begin{array}{l}-0.023 \\
(-1.34)\end{array}$ & $\begin{array}{c}0.27 \\
(0.82)\end{array}$ & $\begin{array}{l}-0.001 \\
(-0.04)\end{array}$ & $\begin{array}{l}0.111 \\
(1.48)\end{array}$ & $16.72 * *$ \\
\hline Grants per capita & $\begin{array}{l}-0.004 \\
(-0.91)\end{array}$ & $\begin{array}{c}-0.060 * * \\
(-6.88)\end{array}$ & $\begin{array}{l}0.020^{* *} \\
3.89)\end{array}$ & $\begin{array}{l}-0.033 \\
(-1.42)\end{array}$ & $55.11^{* *}$ \\
\hline $\begin{array}{l}\text { Time period fixed effects: } \\
\qquad \chi^{2}\end{array}$ & $100.43 * *$ & $70.82 * *$ & $103.19 * *$ & $41.33^{* *}$ & \\
\hline$\overline{R^{2}}$ & 0.76 & 0.73 & 0.78 & 0.64 & \\
\hline S.E.R. & 0.26 & 0.49 & 0.30 & 1.33 & \\
\hline Jarque-Bera & 3.69 & 2.31 & 2.73 & 0.59 & \\
\hline
\end{tabular}

Notes: see table 1, dummy variables for the following regions: Corsica, Picardy, Limousin, Centre and Basse-Normandy. 